\title{
SEVENTY-THIRD MEETING OF THE ASSOCIATION OF RESEARCH LIBRARIES
}

\author{
HELD IN WASHINGTON, D.C.
}

A special feature that preceded ARL's midwinter meeting was an all-day briefing on the Library of Congress, held at LC on Saturday, January 25, 1969. About fifty-five representatives of ARL libraries attended. A tour of the Processing Department began the day at 8:30 A.M. The morning session in the Whittall $\mathrm{Pa}$ vilion, with Librarian of Congress L. Quincy Munford presiding, was devoted to automation. Paul Reimers, Coordinator of Information Systems, summarized developments in automating the CBS (Central Bibliographic System), in MARC II, in the National Serials Data Program, and in RECON (Retrospective Conversion of Bibliographic Records), with mention of the application of computer techniques in the Legislative Reference Service. Paul L. Berry, Associate Director of the Reference Department, described applications of and projects for automation of Reference Department activities. Before a tour of the Card Division, Stephen R. Salmon, Assistant Director for Processing Services, Processing Department, described the optical recognition equipment now in use and explained the plans for completing the automation of the Card Distribution Service, which are awaiting approval of the Joint Committee on Printing.

After a luncheon at a nearby hotel, the group returned to the library for a briefing on the proposed Library of Congress James Madison Mcmorial Building by Robert H. Rohlf, Director of the Administrative Department, and on the Joint Doctoral Program on American Thought and Culture by Robert H. Land, Chief of the General Reference and Bibliography Division. Then the guests spent the rest of the afternoon hearing presentations on either (1) area programs in LC, with African, Latin American, Orientalia, and Slavic and Central European studies being discussed by Julian W. Witherell, Donald F. Wisdom, Warren M. Tsuneishi, and Sergius Yakobson, respectively, or (2) specialized materials-music, prints and photographs, and rare books-with Edward N. Waters, Edgar Breitenbach, and Glenn $\mathrm{H}$. Borders, respectively, describing these collections and programs.

ARL representatives were invited to LC's Friday night concert by the Kontarsky Duo and to the Saturday night illustrated lecture,
"In the Beginning," by Kemp R. Niver, the noted film specialist who played a central role in the conversion of LC's paper-print collection of early motion pictures to projectionable prints.

A formal resolution of appreciation for the visit to LC-" a most informative and pleasant experience"-was later adopted by ARL.

The seventy-third meeting of the Association of Research Libraries was held on Sunday, January 26, in the Diplomat Room of the Shoreham Hotel. ARL President Andrew Eaton (Washington University Libraries at St. Louis) opened the meeting at 2:00 P.M. He introduced substitutes for regular representatives of member libraries and special guests, who included the members of the Executive Board of the International Federation of Library Associations, which had been meeting in Washington, D.C.

Peter P. Muirhead, former Deputy Commissioner and Associate Commissioner for Higher Education and at the time Acting Commissioner of the U.S. Office of Education, spoke on "Legislation on Higher Education and Libraries." Affirming his belief that a good library is the heart of a good college or university, he said that the leaders of those libraries should be major spokesmen for the universities' needs for resources for research.

On December 31, 1968, American higher education completed the most successful decade in history, he declared. Enrollment, which was about three million in 1958 , has risen to more than six million. (This growth in enrollment equaled the increase of the previous three centuries.) It was also a decade of growing maturity. Colleges and universities came to a deeper sense of social responsibility, while America became fully conscious of the potentialities of higher education for all, as well as of the crucial importance of colleges and universities in solving problems vital to our national existence, he said.

Funds for higher education doubled in the decade, climbing to 2 per cent of the Gross National Product-\$18 billion-as compared with 1 per cent, which had been standard for nearly thirty years. Studies indicate that 3 per cent of the GNP will be required by the time the nation is 200 years old, Mr. Muirhead said.

Facing us, however, are many perplexing 
is there a way to end periodical pile-up?

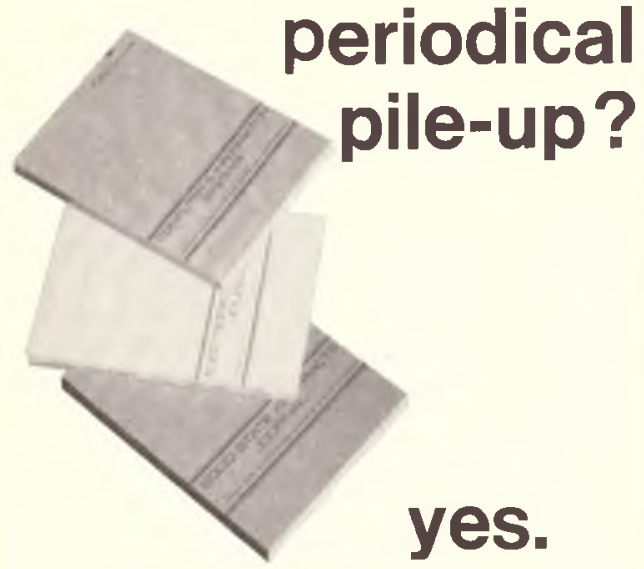

Now, three unique abstracts journals help end the problem of those piles and piles of technical periodicals. SOLID STATE ABSTRACTS JOURNAL, ELECTRONICS ABSTRACTS JOURNAL and COMPUTER \& INFORMATION SYSTEMS provide comprehensive coverage of world-wide sources in their respective fields. Periodicals, government reports, conference proceedings, books, dissertations, and patents are abstracted, indexed, cross-referenced, and published regularly. Librarians and library users alike will appreciate the ease with which pertinent material can be researched. Write for more information, including special low rates and back-issue offer to new subscribers. Make life a little simpler for everybody, yourself included.

Cambridge Communications Corp., 1612 "K" St., N.W., Washington, D.C. 20006, U.S.A.

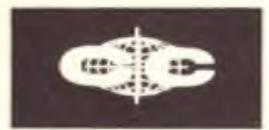

CAMBRIDGE COMMUNICATIONS CORPORATION problems, which "lead us to contemplate the past decade's progress with a rather brittle smile." Higher education must be extended, particularly to those elements of the population which traditionally have been denied it, Mr. Muirhead declared. From the purely economic point of view, this is desirable, because, of every $\$ 5$ of additional personal income obtained in the last decade, $\$ 1$ could be attributed to improved levels of education.

Higher education has also helped enrich the country through the growth of wisdom. We turn increasingly to institutions of higher learning for solutions to acute problems, such as the decay of the cities, he pointed out.

Recognition of the fact that the quality of education has a direct bearing on the fortunes of the nation has led to the increased federal role in support of higher education. The National Defense Education Act of 1958 was "the first of the great laws" accepting this responsibility. As a consequence, science has flowered, returning GI's have had education and have paid the government back in higher taxes, physical facilities have greatly improved, and "bureaucratic conversation has acquired a new fascination for academic types," Mr. Muirhead wryly observed, as he quoted Clark Kerr: "\$4.6 billions a year can make quite a difference."

Before 1958, aid to higher education reflected chiefly support of the government's own interests, rather than of those of the institutions themselves. Since 1958, there has been a totally new pattern-higher education's priorities have not been submerged under federal objectives.

The aid program operates under four principles, he said:

1. Continued support for private institutions, which enroll one third of all students, as well as of public institutions in such a way as not to impinge on their independence. Federal support is and should be pragmatic, and should depend upon whether an institution can be strengthened to serve the public interest better.

2. Strengthening institutions to meet their own missions, for example, the developing colleges, such as Negro and junior and community colleges.

3. Continued emphasis on equality of opportunity. Places must be made for the less affluent; 7 per cent of all college students come from families earning less than $\$ 3,000$ a year, while 48 per cent come from families earning $\$ 10,000$ or more. More than one student in five last year received aid under federal programs. "Racially, the picture is very poor," Mr. Muirhead said; a Negro's chance to attend college is only one half that of the population as a whole. Blacks, he 
stated, are strongly motivated toward going to college in order to improve their status.

4. Recognition of the absolute necessity for institutions of higher education to involve themselves in seeking solutions of social problems, particularly urban problems such as housing, pollution, transportation, poverty, etc.

The people of the United States, in short, are asking that higher education play a major role in shaping American life. The investment is high, but they are willing to pay the price the future exacts, Mr. Muirhead asserted. He expressed his belief that both parties in Congress agree on major educational goals. The 1968 amendments of the Higher Education Act, for example, have the same bipartisan tone as did the NDEA of ten years ago.

Mr. Muirhead then outlined several programs: (1) academic help, especially for the disadvantaged college student; (2) cooperative education, or combined school and work programs; (3) networks for knowledge-cooperative programs for sharing; (4) new programs authorized by the $1968 \mathrm{HEA}$ amendments; (5) help for government workers-for example, for public-service careers; and (6) improvement of graduate programs. He also enumerated programs to strengthen library resources and mentioned grants for training librarians and funding library buildings, acquisitions, and Title II-C, the National Program for Acquisitions and Cataloging or Shared Cataloging Program.

All these programs represent the best efforts of many intelligent men and women, in and out of government, but added programs and money will not invest universities with the magic power to solve all problems. Also, expansion of federal support should not be a signal that other support can decline. On the contrary, federal support should stimulate the flow of money from other sources. Certainly, more and more money is going to be needed, Mr. Muirhead said, for tuition and fees have risen 50 per cent in public and more than 95 per cent in private institutions, and librarians can document rising costs of acquisitions and services.

Despite the impressive "mosaic of federal support," there has been a failure to establish a policy of institutional aid. There is "a cacophony of conflicting views" as to what form this should take, but a pattern must be found. "We must keep the escalating costs of higher education from making the promises of higher education a cruel hoax." There is a "mandate from the American people for equal opportunity and for higher education to go as far and as fast in the service of society as its ambitions and leadership will take it." In conclusion, $\mathrm{Mr}$. Muirhead asserted: "Higher education has giv- en us much; it must give us much more."

In the discussion, the point was made that aid to students is fine but that some pattern of assistance needs to be found that will enable universities to charge the students a real share of the cost of education. Apprehension was expressed that block grants to institutions would only make the problems of librarians more difficult than under specific grants, where costs of library services can be more exactly identified. (Mr. Muirhead said that personally he feels there is need for both kinds of grants-categorical support as well as block support.) The question was raised as to why there are restrictions on certain types of training, e.g., in automation and computer science, that can be given in the institutes. (Ray Fry of the Office of Education and John P. McDonald, member of OE's Advisory Committee, said that suggestions on institute and fellowship programs are welcome but that, to date, training of librarians had been emphasized.)

"Programming Planning for Research Libraries in a University Setting," by Thomas R. Mason, Director of the Office of Institutional Research, University of Colorado, was the second presentation of the afternoon session. Departing from his prepared paper, which he said he had not seen since his final draft was typed, Mr. Mason discussed PPBS-Planning-Programming Budgeting System-the "most remarkable contemporary product of administrative science." PPBS originated in the Department of Defense under Secretary Robert S. McNamara, and in 1965 President Lyndon B. Johnson directed that executive agencies use this approach. Since then, Mr. Mason said, it has swept the nation. He discussed how university planning, especially program planning for the research library, is taking place within the PPBS approach.

Essentially, he said, it is planning where we are going and persuading others that these goals are valid, obtaining the resources, and organizing them. When one looks at the university as a system, with the traditional tripartite division into instruction, research, and public service, the research library may be viewed as a subsystem, a supporting resource "so interlocked with the purposes and functions of the university that the program objectives are closely correlated." Program budgeting is simply the allocation of resources and the control of their use in order to get the most out of them in obtaining objectives.

It is easy to prepare the Student Instruction Model, showing the students coming into the university, flowing through, and going out, but it is remarkable, he said, how little we know about what happens to the student while there. The Research Model conceives of current knowledge as input and revised or new knowl- 


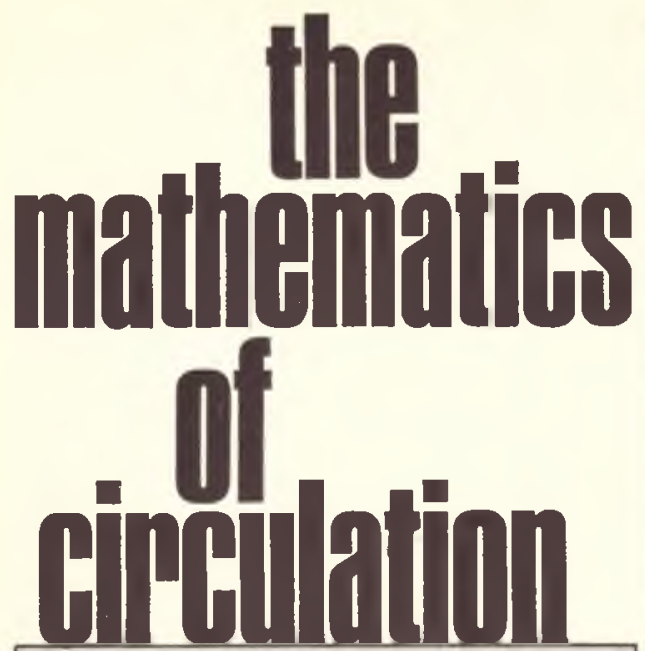

We'll admit that purchasing can be very confusing, particularly when some suppliers offer prices which may "seem" very low.

Take binding, for example, whether it's for new books or used ones. How do you check the true cost?

Here's the simplest wayl

You know that a book bound by a Certified Library Binder will provide at least 100 circulations. Divide the cost of the binding by 100 and you get the cost per reader. Now do the same with a book offered in any other binding (if you can establish the number of circulations) and get the answer.

Only with Certified Library Binding can you be assured of maximum circulation which means lowest cost per reader. That's because the materials and workmanship which are part of every book bound by a Certified Library Binder are controlled by minimum standards set by the Library Binding Institute. It's also because a qualitycontrol program, to which every member of the Library Binding Institute subscribes, guarantees you the longest-lasting books available.

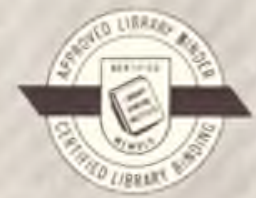

Make sure that your Library Binder displays this seal. If he doesn't, then find one who does, so that you will get the most for your dollar. There are fewer than 60 Certified Library Binders in the United States. We'll be happy to send you the list without obligation, and we'll also include some other interesting literature.

\section{Library Binding Institute}

160 State Street Boston, Mass. 02109 edge as output of the research program; and the public service program is similarly modeled. Faculty and supporting staff, buildings and equipment, libraries and other academic services, as well as the research and public-service programs, constitute the input for instruction.

Most university planning now starts by projecting student enrollment. Faculty requirements, based on teaching loads at the undergraduate level, are then calculated. Expected program changes are also envisioned. These factors affect annual academic planning and budget preparation, and from them longerrange estimates of the need for personnel, buildings, and other resources, to say nothing of the costs, are projected.

In the last decade, we have been playing the numbers game, Mr. Mason asserted. There are computer programs for predicting how many students are going to college and even "where they may land," how many will take what courses and what the faculty needs there will be, but what the research faculty is going to do is still unpredictable, he said. The more obvious dimensions of program development may be foreseen, however, and thus the demands on library resources may be estimated.

Goals and objectives are what people disagree about, but, by using quantitative analysis, the PPBS approach minimizes this. Through "resource allocation," or budgeting, the administrator increases his control over program development. And, finally, through systems analysis and cost-benefit studies, "economic rationability" can be applied to defining goals and selecting programs.

There are recognizable dangers in this approach, Mr. Mason acknowledged. No one, he said, has really devised a satisfactory programbudgeting system for a university, and he emphasized that planning (systems analysis) "is not a cut-and-dried, step-by-step process, but it is a highly heuristic, intuitive, and pragmatic art ... a skill that any modern administrator must have."

University administrators and planners must join with librarians, he felt. The former look upon the university library as a major resource, and, in his experience, Mr. Mason said, defining the library's future needs for buildings, collections, and services has provided the best index to other university needs of the future. "I suspect," he continued, "that the research library can do a more effective, in-depth job of internal program-planning than the university as a whole because of the more concentrated purposes, the more coherent organization, and the relatively smaller scale of the research library."

Demands for services, materials, and facilities - to support the instruction programs, the 
research programs, and the community-service programs "which are coming on big and fast because that's where the money is"-shape the basic programs of the research library. Because of "the identity of purpose between the university and the research library, the development of systematic, comprehensive program planning must proceed hand-in-hand," and Mr. Mason said in conclusion that "the university can learn much from the leadership of its librarians."

A three-man panel then spoke. Robert Blackburn (University of Toronto Library) observed that he found himself in the somewhat awkward position of commenting on a paper that he had read but had found that the speaker had not agreed that libraries in universities should lead the way in program-planning but pointed out that most university librarians are victims of new professors in new fields appearing without notice on the doorstep and expecting library resources that it might take years to obtain. He also observed that it is difficult to measure output (results), and he maintained that a great book collection creates its own demands-that user demands do not necessarily grow out of the classroom. He also felt strongly that a library is more than a support program but is a major resource as much as the faculty is- $a$ point both faculty and administrators often overlook.

Warren J. Haas (Charles Patterson Van Pelt Library, University of Pennsylvania) dryly defined operations analysis as the development of sophisticated techniques to arrive at simple conclusions and questioned whether there is a danger that the techniques will tend to homogenize education. May not one institution tend to copy another model? There must, he felt, be room in planning for the experimental, the unorthodox, the drastic. He especially felt the need for reviewing results, "You have the haunting feeling that once the budget is out, one loses sight of the plan." In light of ARL studies, what information is needed by university administrators and planners? he asked. Should research libraries have planning officers and should university planning staffs have full-time librarians on them? Library programs are not mirror images of university programs, he declared, and he agreed that resources generate demands. Research libraries are part of the national picture, part of the national resources, and must be considered accordingly.

David Kaser (Cornell University Libraries) took the view of the library itself, rather than of the university as a whole. The planning that Mr. Mason's paper pictures should be greatly welcomed, he said. "We think we know, but we've really flown by the seat of our pants. We haven't had much hard data." He agreed that the libraries may be able to implement such planning faster than the university as a whole, because the library's mission is homogeneous, libraries are automating, they are more subject to change than the university as a whole, and libraries are structured for quicker decision-making. "If we can learn to use these modern weapons before the university learns to turn them back on us, it will be to our advantage," he said, and he felt that "there is enough data floating around now to enable us to plan more effectively."

Mr. Mason agreed that the fact that the Iibrary creates its own demands is very significant. Also, he recognized that, although it is possible to project today's distribution data, when Professor $\mathrm{X}$ has ten students the first year and 250 demand his course the next, it is impossible to plan. However, "even fairly loose, freewheeling quantification focuses on quality," he felt, but "we don't know how to measure qualitatively. We keep trying to rationalize planning; someone notices that a certain percentage of funds available went into libraries last year, so it is assumed that the same percentage will do this year. Seat-of-the-pants judgments become the input, time and again."

In response to discussion from the floor, Mr. Mason expressed the belief that the university library should have not one planning officer but two or three. Data, even where they exist, need to be put together, to be analyzed and mobilized. "The battle for resources," he said, "is going to become more and more political" in the general sense of the word.

After a recess for dinner, the business meeting was convened by President Eaton at 7:00 P.M.

Greetings on behalf of IFLA's Executive Board and other European colleagues were brought to the meeting by Joachim Wieder, Direktor, Bibliothek der Technischen Hochschule in Munich, IFLA Board member. The ARL, he said, works not only for America but with libraries of other nations in mind. A chapter has yet to be written about the impact of American library development on libraries of the world. IFLA, too, is seeking new methods for professional work, Dr. Wieder said, and expressed his pleasure at being able to get to know the "incarnation of American libraries" through the meetings of the ARL and ALA.

President Eaton announced that the libraries of the University of Alberta, University of California at Davis, Case Western Reserve University, Dartmouth College, and the University of Massachusetts, as well as the New York State Library (Albany) had been selected for ARL membership.

Stephen A. McCarthy, ARL Executive Director, reported that:

1. ARL's new address is 1527 New Hampshire Avenue, N.W., Washington, D.C. 20036. 
2. A management study of university libraries is needed and ARL's Board has authorized a proposal for an initial study of a few libraries to be carried out by a management firm.

3. The Slavic Bibliographic and Documentation Center seems assured for a three-year period. (A $\$ 350,000$ Ford Foundation grant for this was announced by ARL on March $10,1969$.

4. The New York Times has refilmed issues from October 1967 to March 1968 but inspection is still necessary because inferior film has been supplied for the period following 1968 and there are reports that some of the replacement film is inferior.

5. The lighting study has not been completed, but the Council on Library Resources has approved an extension until July 1969.

6. The study of the economics of book storage, funded by the Educational Facilities Laboratory, is now in draft form, is being reviewed, and should be completed in the spring.

7. The publication date of the comprehensive list of chemical journals being issued by Chemical Abstracts is late September 1969.

8. The Board voted official and formal thanks to $\mathrm{LC}$ for the visit mentioned above.

P. K. Yu, Director of the Center for Chinese Research Materials, reported on the reproduction of materials and on bibliographic control. The center can take on large projects, determine their value to the academic community, and not worry about the profit motive. LC has lent most of the material, and the New York Public Library has conducted relations with the National Library in Peking on behalf of the center.

The three national libraries (LC, NAL, and NLM) distributed reports, and their directors mentioned only a few main points.

The Librarian of Congress stressed the need for the third building if $\mathrm{LC}$ is to be able to serve the nation. Additional funding for Title II-C of HEA will also be necessary if that program is to be continued and extended as planned and as ARL desires. It cannot operate at a higher level than last year because of mandatory salary increases and because $\$ 500$,000 of the $\$ 5.5$ million voted for fiscal 1969 must finance the Monthly Index of Russian Accessions, formerly funded by HEIV from other sources. The $\$ 7,376,000$ approved by the Budget Bureau in HEW's requests for fiscal 1970 will permit normal expansion of this program but very little implementation of the activities approved in the 1968 amendments to HEA. It is essential that automation in LC, which is central to such developments in other libraries, also be adequately funded.
John Sherrod (NAL) reported that the exterior of NAL's new building was completed last October, the interior will be finished in February, and the staff and the collections are scheduled to be moved in April 1969. A computer will be installed before the building is occupied. The final report on a design study of an automated document location and control system is now being studied. Emphasis is being placed on compatibility with NLM, LC, MARC II, and COSATI formats and standards previously accepted by USASI, Mr. Sherrod said. Top priority is being given to inventory control, and an effort will be made to update records as they move through the library. It is hoped that a mechanized NAL will serve as a principal node in an international agricultural information system as well as the coordinating agent in an NAL network serving domestic users.

Dr. Martin M. Cummings (NLM) said that the accomplishment of the planning for a Biomedical Communications Network, approved by the Library's Board of Regents at its March and June 1968 meetings, was the most significant development of the year. The first phase of this five-part program, the library services component, had been substantially completed. It represents an extrapolation of the system of regional medical libraries and MEDLARS search centers already under devlopment. The second component (specialized information services) is based on the Toxicological Information Program and will seek to link other special computer-based biomedical files. During the coming year the third component (specialized education services), applying telecommunications technology to medical education, will be given priority. The fourth would develop the capacity of the National Medical Audiovisual Center in Atlanta, transferred to NLM in 1967, to provide such educational materials, and the fifth will be the data-processing and datatransmission component, or hardware and systems support for the program areas mentioned.

NLM's research and development staff, headed by Ruth N. Davis has been reconstituted as the Lister Hill National Center for Biomedical Communications, authorized by Public Law 90-456 to honor the Senator from Alabama, who did not seek re-election. Dr. Davis is the director. Other developments at NLM include a shared-cataloging arrangement (involving a common machine-readable input) with the State University of New York's Upstate Medical Center at Syracuse, and the Francis Countway Medical Library at Harvard University; and a system for MEDLARS II, to be delivered in March. For awhile, two systems will have to be operated, but MEDLARS I, which now has a million citations in the file, will be phased out.

Gordon R. Williams (Center for Research 
Libraries) reported that the center now has thirty-eight members. Greater emphasis is being placed on direct acquisition, for which $\$ 400,000$ was available this year. For its newspapers on microfilm (U.S. and foreign), $\$ 100,000$ was expended last year. Being acquired are sixty current newspapers, including twenty Negro newspapers, all Public Law 480 newspapers that LC is microcopying, U.S. archives on microfilm, U.S. captured German records, and some microfilmed foreign records. CRL, within limitations of funds, will acquire on demand for its members U.S. or foreign newspapers and archives on microfilm. Mr. Williams also announced that the center will begin to microfilm deteriorating materials in its members' collections and that NLM, NAL, and CRL will divide a set of P.L. 480 publications, including a full set of government documents. The catalogs in book form are at the printers; that of newspapers will be out in February and those for books and serials will follow. All will be generally available. Effective July 1, the center's newsletter will be available only to members. There is an associate membership for smaller libraries, but they have no representation or vote in CRL's council.

Louis E. Martin (ARL Washington Office) reported on the ARL Microform Technology Project. A report by the director of the project, Donald C. Holmes (formerly Chief of LC's Photoduplication Service), was distributed. The project, funded by $\mathrm{OE}$, was designed to identify the needs of users of microforms and to determine what factors in microform technology impede the use in libraries of materials in this form. Interviews, rather than questionnaires, were used. The final report will concentrate on concrete recommendations.

A number of committee reports were submitted in writing and were only briefly summarized. Arthur M. McAnally (University of Oklahoma Libraries) presented a Model Interlibrary Loan Code for Regional, State, and Other Special Groups of Libraries. The ARL Board endorsed this, and the membership approved. It stated, among other things: "In order to prevent severe cutbacks in interlibrary lending or the elimination of it altogether, it may now be time to recognize that free interlibrary loan service is no longer practicable and to accept the principle that lending libraries cannot be expected to bear the full costs of interlibrary loan service. Failure to recognize this fact could bring about the collapse of the system as we have known it, perhaps not all at once but by the steady withdrawal of library after library from the system."

Robert B. Downs (University of Illinois Library), reporting for the Standards Committee, said that an elaborate questionnaire had been distributed to fifty selected libraries and that only three had not replied. An analysis of the data should be ready this spring. Dr. Downs emphasized that the committee is not trying to develop standards now but rather criteria for excellence.

Verner W. Clapp (Council on Library Resources, Inc.), Chairman of the Copyright Issues Committee, reported that the Copyright Revision Bill (S. 543) had been reintroduced in Congress, including the proposal for a commission to study new uses of copyrighted works; that the ARL and ALA are working together to obtain the statutory right to copy for research, for display, etc.; and that CLR had convened in Washington on January 10, 1969, a small meeting on the photocopying of manuscripts in library collections. That group agreed to recommend to ARL libraries that photocopying of manuscript for study or research should be freely permitted, with reasonable limiting dates to be set by administrative action. Some twelve other considerations affecting such photocopying were also identified. The ARL business meeting agreed that the ARL's two policy statements in this field-the Materials Reproduction Code (1940) and the statement on the Use of Manuscripts by Visiting Scholars (1951) -were in serious need of updating and that this should be done.

John G. Lorenz of LC, Chairman of the Foreign Newspaper Microfilm Committee, which has expanded its scope beyond $C R L$ 's Foreign Newspaper Microfilm Project and is now considering the development of a National Foreign Newspaper Microfilm Project, reported that ARL's Board had approved the committee's proposal for a study to identify what should be acquired, what cooperative arrangements could be made, what the specifications should be, and what institution should have oversight of such a program.

Thomas R. Buchman (Northwestern University Libraries) said that since LC has to give up the indexing of Disseriation Abstracts, an agreement had been made with University Microfilms to conduct an experiment using DATRIX. A larger sampling than UM had contemplated should be undertaken, he felt, and then a comparison could be made with LC's subject-heading approach. A table had been made up showing the length of time it takes to get the microfilmed or electrostatic copies of the dissertations, and ARL libraries were urged to review this. UM is considering including foreign dissertations, in addition to the Canadian ones which are now included. Gustave A. Harrer (University of Florida Libraries) reported that a meeting with several European librarians had been held in the United States and that West German universities now have a consortium to obtain a copy of every study listed in Dissertation Abstracts. 
Robert Vosper (University of California at Los Angeles Library), Chairman of the new Federal Relations Committee, said that much attention has been given during the year to defining the scope of its responsibilities and to guidelines for Title II-A of HEA. The committee had worked closely with leading Members of Congress concerned with library and education legislation. He proposed that ARL approve —and it did-a draft of a resolution endorsing the report of the National Advisory Commission on Libraries in general and in particular those recommendations calling for support of LC and HEW, a permanent National Commission on Libraries and Information Science, and recognition of $\mathrm{LC}$ as the national library.

James E. Skipper (University of California at Berkeley Library), Chairman of the Committee on Automation, reviewed his committee's session at Kansas City, where bibliographic services in machine-readable form were discussed, and the first two meetings of the Advisory Committee to the three national libraries' Task Force on Automation, on which Dr. Skipper represents ARL. MARC II as a standard format and efforts to make the systems of the three national libraries mesh were the main topics at these meetings. It is the conviction of the committee, Dr. Skipper said, that the retrospective bibliographic record must be converted to machine-readable form, the problems of which are now being studied by RECON.

\section{Expert Service on}

\section{MAGAZINE SUBSCRIPTIONS}

for

ALL LIBRARIES

\section{FAXON LIBRARIAN'S GUIDE}

available on request

Fast, efficient, centralized service for over 80 years. Library business is our only business!

\section{F. W. FAXON CO., INC. \\ 15 Southwest Park}

Westwood, Mass. 02090

Continuous Service to Libraries Since 1886
It was noted that the Foreign Acquisitions Committee has replaced the Farmington Plan Committee and that the Committee on NonGPO Publications is concentrating on improved coverage of these materials in the Monthly Catalog of Government Publications issued by the Superintendent of Documents, Government Printing Office. The main accomplishment of the Committee on Availability of Resources, Chairman Ralph Hopp (Michigan State University Library) reported, has been the presentation to the ALA of proposals on interlibrary loan, which were prepared by Mr. McAnally. Scotty Cameron, who served as ARL interim executive secretary before Dr. McCarthy's appointment, announced that he is doing a study for CLR on the economics of the library profession. Statistics are in disarray, and figures are needed to convince university administrators of library needs, as well as to create the climate to attract bright young people. "Unlike most of the other speakers," Mr. Cameron said, "I am not prepared to answer any questions!"

Gordon Williams (CRL) and Herman Fussler (University of Chicago library) had been asked to study the problem of dealing statistically with microforms, and they suggested a formula for counting them as volumes. A formal dissenting statement was presented by Dr. Downs. After considerable discussion, the proposal was voted down because it was felt that to count a microform of a work (or a number of microforms) as a volume was to build up statistics "fictitiously"; comparability of statistics with other libraries would be lost (for example, ALA's report on statistics calls for reporting volumes and microforms separately); and faculty and other scholars, according to two informal polls reported by members, preferred separate categories. On the other side, some felt that the content, not the form, was the important thing and that statistics were largely for public-relations purposes anyway. Warren J. Haas, Chairman, filed a report on the Preservation Committee. It will assess the current stateof-the-art, will seek further data on the need for basic research, will promote the use of permanent durable paper, and will concern itself with the development of a detailed national preservation plan based on the objectives of the Williams Report. The annual report on Standard Committee Z39 Library Work and Documentation, of which Jerrold Orne (University of North Carolina Libraries) is chairman, listed a number of draft standards on which work had been done.

Results of the balloting, which took place earlier in the business meeting, were announced. Elected as members of the Board of Directors were David Kaser, John McDonald (University of Connecticut Library), and Robert Vosper. The Vice-President and President- 
elect is now chosen by and from members of the board, and Warren J. Haas was so elected at a later meeting of the board. After warm words of thanks for Dr. McCarthy's contributions and the announcement that the next ARL meeting will be held on Saturday, June 21, 1969, at the Shelburne-Empress Hotel in Atlantic City, President Eaton turned over the gavel to Douglas Bryant (Harvard University Library), incoming President, who-after two long days of concentrated attention to library programs and problems-mercifully carried on the ARL tradition of no inaugural speeches, thus beginning his regime with warm good wishes from all.

\section{ARL January Meeting-Addendum.}

Not reported at the seventy-third meeting of the Association of Research Libraries was an action of its Board of Directors that is of particular interest and gratification to the Library of Congress and of significance in the effort to achieve standardization in library automation.

The Advisory Committee to the U.S. National Libraries Task Force on Automation and Other Cooperative Services, at its meeting on July 11, 1968, agreed to recommend to the governing bodies of each of the national library associations represented on the committee the adoption of the following resolution:

Because the MARC II format has been adopted by the three National Libraries as their standard format for exchange of bibliographic information, and

Because the MARC II format has also been adopted by the British National Bibliography, and

Because MARC II is the de facto national standard and contains more bibliographic elements than most libraries require, and

Because the Library of Congress intends to produce all machine-readable output in the MARC II format and intends to create a national data base for monographic materials in this way, the National Libraries Task Force Advisory Committee recommends that-

The MARC II format be endorsed by the various national library associations as the national standard for communication of bibliographic information, and that

The endorsement be widely publicized in the professional journals published by the associations and in such other ways as each association may deem suitable for informing its membership, and that

Each association strongly urge its members to adopt this format for communication of bibliographic information between themselves as well as in relaying information to the National Libraries.
ARL's Board of Directors, at its meeting on January 26, 1969, voted endorsement of this resolution. In transmitting notice of this action to the Librarian of Congress, ARL Executive Director Stephen A. McCarthy said: "We hope that the adoption of this resolution will strengthen the commitment to the MARC II format and help to assure its general adoption by American libraries."-Elizabeth E. Hamer, Library of Congress.

\section{BIBLIOGRAPHY ON LIBRARY COOPERATION}

The Library Research Center, University of Illinois, is compiling an annotated bibliography of cooperation between libraries of different types. Because of the elusive and ephemeral nature of much of this material, the Center has experienced difficulty in locating it through the standard indexing tools. The Center is interested in:

1. all materials describing actual instances of cooperation between libraries of different types (i.e., academic, school, special and public libraries) since 1940;

2. all such reports written in English throughout the world;

3. all present plans to establish cooperation between libraries of different types.

Both citations and actual reports will be welcomed and all inquiries and correspondence should be addressed to Galen E. Rike, Research Associate, Library Research Center, 428 Library, University of Illinois, Urbana, Illinois 61801.

\section{ISAD ANNOUNCES TWO EXPERIMENTAL TUTORIAL SESSIONS}

- Sunday, June 22, 1969, Atlantic City

Hotel to be announced later

- Sunjects

Session One: Elementary Systems Analysis

Session Two: Basic Machine Functions

- FOR ISAD personal members only

- Each session limited to 100 persons (divided into four groups of 25 each).

- No charge

Registrations will be accepted from ISAD members who wish to learn about automation, systems, and the function of the various machines used in typical automated libraries. Specify which of the two topics you wish to attend. Mailed registrations only will be accepted in order of their receipt.

Address them to Tutorials, American Library Association, 50 East Huron Street, Chicago, Illinois 60611 . 